\title{
Gentlemanly Professionals and Men-about-Town: Occupational Identities amongst London Advertising Men, 1951-67
}

In Portrait of a Decade, his autobiographical reflections on the opening up of London life in the first ten years after the War, Evening Standard journalist Douglas Sutherland suggested that the 'advertising executive' was the most emblematic figure of the 'changing atmosphere' that took hold as the city emerged from the gloom of the immediate post-war years. In 'a dark-grey suit armed with his lavish expenses account ... [he] commanded the best tables in the most expensive and exclusive restaurants'. For Sutherland, these advertising executives embodied the 'new air of buoyancy' in London's expanding economy, alongside 'the bankers, the stockbrokers and the wheeler-dealers of the City' and the new cadres of industrialists and property developers. ${ }^{1}$ It was 'admen', however, who led the way amongst this group of entrepreneurs, defining a new style of 'business executive with the slim briefcase, the rolled umbrella and dark-grey suit'. ${ }^{2}$

Sutherland's placing of the 'advertising executive' at the heart of the commercial renaissance of the capital city registered important changes in London's post-war economy. Employment in manufacturing and the docks fell sharply, their decline accelerating between 1961 and 1973. At the same time sectors like fashion, design, magazine publishing and advertising brought nearly a quarter of a million jobs to London in the 1960s. These employment trends consolidated the already dominant position of service work in the capital and were given a further boost by the relaxation of planning laws and the rise of property speculation in the late 1950s and early 1960s. This produced a surge in new office building and contributed to the growth in London of relatively high skilled service employment, including advertising. ${ }^{3}$

The expansion of advertising employment in London strengthened the close historical association between the advertising industry and the commercial geography of the capital 
city. The majority of agencies were based in the West End of London from Mayfair and Knightsbridge, through Holborn, the Tottenham Court and Euston roads to the Strand. Others were located in offices towards the eastern parts of the city near to London's financial district and close to Fleet Street and its surroundings lanes. ${ }^{4}$ Whilst there were advertising agencies in Britain's other big cities, including regional offices of the large agencies, London was the unchallenged centre of advertising in the UK. Advertising's post-war growth, whilst it had a broader national and international significance, was generated from within the specific spaces of London's commercial geography.

This embedding of the advertising industry within the commercial milieus of the city did much to shape the identities of advertising practitioners. Their public profiles owed much to the cultural geography of central London as they assembled distinctively urban identities within the spaces of the capital's business, entertainment and leisure districts. Taking my cue from Douglas Sutherland's reference to the post-war figure of the 'advertising executive' and his contemporary style, this article explores the urban, metropolitan dimensions of the identities forged by these practitioners during this buoyant period for both the city and the industry. In doing so, I focus upon their appropriation of the identity of the gentleman and the associated codes of gentlemanliness, charting the influence of these patrician styles and dispositions upon London advertising men. Gentlemanliness had a particular currency within London life during the 1950s and 1960s, forming part of the City's distinctive parade of urban social types. ${ }^{5}$ As Frank Mort has shown, the currency of gentlemanliness owed much to the continuing influence of the gentry and styles of patrician masculinity. Contesting established accounts of the decline of aristocratic influence after 1945, including assertions about their diminished political power and social status, Mort argues that upper class institutions and personalities transformed themselves to become key players in the making of London's post-war culture. He shows how patrician models of behaviour and public display, 
including the reappearance of the persona of the 'man- about- town', were reworked in forward looking ways as members of the gentry re-invented aristocratic identities. ${ }^{6}$

Gentlemanliness, however, was also adopted by groups outside the aristocracy in ways which were often backward rather than forward-looking in their inflection of patrician style.

The article explores this more conservative appropriation of patrician style within London advertising amongst senior advertising men. In doing so, it treats gentlemanliness as a set of subjective dispositions and attributes that were appropriated and lived out by men who were typically not from upper class backgrounds. In exploring the ways in which they took up the codes and styles of gentlemanliness, the article foregrounds the gendered dimensions of their occupational identities. It draws on established thinking about and theorizing of masculinity to do so. ${ }^{7}$ This has insisted on the plural forms of masculinity and its articulation or interweaving with other dimensions of identity. Out of this conceptualization has come a fruitful and capacious body of scholarship on the intersection and interdependence of masculinity with ethnicity and race, sexuality, occupation, status and class. These accounts of distinctive formations of masculinity have also attended to their fashioning through specific social practices and within particular cultural spaces or milieus. ${ }^{8}$ Drawing on these arguments, the article shows how gentlemanliness in the 1950s and 1960s represented a form of masculine identity and comportment organized through patrician codes of behaviour and display and interwoven with gendered ideas of the national character. It was principally lived out by advertising men within the largely homo-social spaces of London's business and entertainment districts and forged through the professional and leisure-based rituals of the industry.

The piecing together of this account of the place and role of gentlemanliness within the culture of post-war London advertising is carried through a brief study of the lives and careers of two notable advertising men who had climbed to senior positions within the 
industry by the early 1950s. They are Hubert Oughton and Ashley Havinden. Both men worked for the large British agency W.S. Crawford. I argue that gentlemanliness had a particular currency for men like Oughton and Havinden because it performed important symbolic work for them, offering a way to elevate the social standing of their occupation. Such a strategy of occupational elevation was neither unique to them nor to advertising. Rather it had precedents. Since the late nineteenth century, professions like medicine, the law, engineering and architecture had consolidated their social standing by taking on some of the attributes and personal qualities of the leisured gentleman. ${ }^{9}$ This could involve aping the forms of public display associated with the gentry. Gentlemanliness, however, was also borne of an ethic of service, self-control, restraint and reticence. ${ }^{10}$ It was additionally marked out by its opposition to the instrumental, the coarse, the vulgar and the self-promoting. ${ }^{11}$ Tellingly, this placed the ideal gentleman professional above the grubby world of trade and commerce, superior to the vulgarities of the self-made man. ${ }^{12}$

Advertising practitioners had drawn on this strategy of occupational elevation from the early part of the twentieth century and had sought to align themselves with the social recognition afforded to the established professions. ${ }^{13}$ In the 1950s and 1960s, this recognition was at its zenith. In fields as diverse as economic management and social and cultural policy, the expanded authority of professional experts was one of the defining features of British life. ${ }^{14}$ For Harold Perkin, in his celebrated study of the rise of 'professional society', such was the power and pervasiveness of professional expertise that it was competition between professional hierarchies, rather than class conflict, which defined the social order through much of the twentieth century. ${ }^{15}$ Yet, if the standing of professional expertise remained high in the immediate post-war decades, the evaluation of gentlemanliness underwent more marked shifts. As Marcus Collins has shown, gentlemanliness slipped from occupying a secure place within the national culture in the mid-1950s to being subject to sustained 
criticism, especially in the wake of the Suez crisis and the Profumo affair. As the mask of disinterested service was punctured, gentlemanly rule was revealed to be compromised by its duplicity and its self-interested defence of its privileges. Furthermore, from being the bedrock of British success, gentlemanly codes of honour were identified in critical commentaries as the principal cause of Britain's decline. Even the reputation of national heroes suffered. Whilst in the late 1940s Captain Robert Falcon Scott - Scott of the Antarctic - represented all that was best in the British national character, by the 1960s he came to represent another example of the 'bungling gentlemanly amateurism' responsible for the country's economic and political decline. ${ }^{16}$

These shifts in the social valuing of gentlemanliness made it a less secure identity for advertising men to lay claim to as the 1950s turned into the 1960s. For men like Oughton and Havinden, however, it continued to have force partly for generational reasons and partly because of other dimensions of the cultural climate that specifically bore upon advertising. This was the wider hostility to advertising which flourished in the 1950s and 1960s. The critics of advertising were on the rise in these years, stirred in part by the arrival of commercial television and by the apparently growing influence of advertising upon social life. Whilst there was a long-standing critique of advertising going back to at least the early nineteenth century, the hostility expressed towards advertising by critics reached a new peak in the immediate post-war decades. As industry insiders complained, it had become almost an article of faith for liberal and educated opinion to be antagonistic towards the advertising industry. The success of popular books like Vance Packard's Hidden Persuaders, as well as a larger body of social and cultural criticism which looked at what it perceived to be the negative social consequences of mass persuasion, put advertising people on the back foot. ${ }^{17}$ This critical climate meant that advertising people were often defensive about their social role and did not feel as central as some contemporary commentators saw them as being to the 
cultural life of London and the wider national scene. For advertising men like Oughton and Havinden, formed in the inter-war period and shaped by earlier moves to promote the professional standing of advertising practitioners, the post-war criticisms of the industry reinforced the contemporary pull of gentlemanliness. At the same time, however, it also put them outside the newer image of the 'Swinging adman' associated with a younger generation of advertising practitioners lionised by critics like Christopher Booker and magazines like London Life and the Sunday Times magazine in the mid-late 1960s.

If Oughton and Havinden were distanced from the styles of younger admen by the mid-late 1960s, then the established codes and styles of gentlemanliness had a continuing purchase on their occupational identities for another reason. They allowed Oughton and Havinden, and the agency that they worked for, to emphasize their Britishness at a time when US advertising agencies were an increasingly powerful presence within London advertising. Fears about the Americanization of British advertising and wider British society often focused on the cultural effects of the brash styles of US commercial culture and the persona of the Madison Avenue 'huckster' ${ }^{18}$ For men like Oughton and Havinden, drawing on gentlemanliness provided a way to assert their cultural distance from these American influences. As leading figures in the management of Crawfords their self-presentation was part of a broader strategy to emphasize Crawfords 'classiness' and Britishness against the personal styles and communicative ethos of US advertising. They were not unique in doing so. It was a strategy pursued within the heartland of US advertising by the most famous British advertising man of the period, David Ogilvy. Ogilvy built a career in New York by cultivating a public image of the sophisticated, tweed-wearing, pipe-smoking English gent. The advertising that he produced and which became the trademark of his agency, OBM, was carried through restrained, understated forms of selling that drew upon his gentlemanly profile and was famous for its address to the status striving 'snob in you'. ${ }^{19}$ This played to an American idea of Britain centred upon its enduring 
aristocratic traditions and civilized gentility. The appeal of gentlemanliness to British advertising men in the 1950s and 1960s, then, was driven by the twin desires to raise the occupational standing of their profession and by the assertion of a distinctively British ethic of advertising in the face of US commercial power. Both strategies had precedents in interwar advertising and were drawn on and inflected by men like Oughton and Havinden - both of whom were formed professionally in the 1920s and 30s - in the different cultural climate of post-war Britain.

There is a final point to make about the formation of gentlemanly identities within London advertising. Whilst I foreground the role and place of gentlemanliness in the self-presentation of Hubert Oughton and Ashley Havinden, it will become clear that it formed only one part of their multi-faceted identities. Both men also drew on other occupational identifications. The first of these, most evident in Oughton's self-presentation, was that of the businessman. The other, most evident in Havinden's public profile, was that of the advertising man as artist and designer. The pull of these other occupational identities tells us much about the hybrid nature of advertising as a practice. It was a practice structured around the accommodation of three occupational logics: professionalism, an entrepreneurial or business ethic and ideas of 'applied creativity'. These three logics worked to unsettle any secure occupational identity for advertising, dividing it from within along different logics of practice. Oughton and Havinden lived out these divisions in their professional identities, with the identifications they made with private enterprise and art and design cutting across their appropriation of the codes and style of gentlemanliness.

\section{The World of Advertising in Post-war London}

The journalist Anthony Sampson suggested in his Anatomy of Britain, a study of the new patterns of power and influence in the post-war period, that advertising was one of the parts 
of British society that was 'on the up' ${ }^{20}$ Whilst his account may have been blind to the earlier inter-war growth of advertising and the close ties that some senior advertising practitioners had managed to secure within the corridors of power in the 1920s and 1930s, Sampson's observation captured the rapid rise in the advertising industry's economic fortunes on the back of the recovery of advertising expenditure after the war and the associated growth in advertising employment. ${ }^{21}$ The buoyant industry identified by Sampson was dominated by the large London based agencies. In 1962, the five biggest placed a quarter of all advertising and around half of all advertising was handled by the top fourteen agencies. ${ }^{22}$ By the end of the 1960s, 6 of these top ten advertising agencies were US-owned. This 'American Invasion' accelerated the transfer of American know-how and commercial expertise across the Atlantic, a process that had been happening since the 1920s. It also worked to reinforce the dominance of the big London-based agencies over the market for advertising services in the UK as these agencies often had close links with the high spending multi-national (especially American) advertisers. $^{23}$

The majority of the large agencies, including the American-owned ones, were members of the Institute of Practitioners of Advertising (IPA). The Institute was a significant force in the life of the industry during the 1950 s and 1960 s. It claimed that $85 \%$ of all advertising placed in Britain was done by its members. As the industry that it represented expanded, so too did the Institute. Its membership grew from 650 individual members in 1953 to 2,100 in 1965 , about 1 in 10 of those employed in the industry. Agency membership of the IPA likewise rose from 200 to 270 member agencies in the same period, representing around half of all registered advertising agencies in the UK. ${ }^{24}$ In the midst of this confident blossoming, the Institute produced a second impression of its Aims and Functions in the mid-1950s, together with a range of new publications. The tone of many of these publications was upbeat and forward looking. Institute Information, the IPA's members' journal, revealed an organization 
keen to emphasize its status as a respectable professional body. Photographs of the interior of the IPA's impressive HQ in one of Belgravia's most exclusive squares were reproduced, along with reports of the IPA's luminaries and members enjoying themselves at the annual dinner and dance or at social events and exhibitions. ${ }^{25}$ Through this sort of coverage, Institute Information offered a glimpse of scenes of genteel social intercourse, showing an organization with a clear eye on associating itself with the signs of social respectability.

The sociability fostered by the IPA amongst its members was elaborated in the more exclusive advertising clubs. Frequented by those at the upper echelons of the industry, their memberships overlapped with the senior members of the IPA and those who sat on its numerous committees. Perhaps the most important advertising club was the Thirty Club of London. Established in 1923, it provided a private dining club for top industry men and was a place to listen to and mix with invited speakers from the world of business, the arts and politics. In the 1960s, the club met at the Waldorf Hotel, near the High Courts and theatreland in central London. ${ }^{26}$ A similar mix of congenial company and informal business talk took place at the Art's Club in Dower Street, off Trafalgar Square. The Art's Club, like the Thirty Club, aped the style of the established gentleman's clubs, but was the preferred meeting place of top creative practitioners. Capturing this association with advertising in the early 1960s, Anthony Sampson suggested that from the bar of the Art's Club 'can be heard the braying sound of admen on the move'. ${ }^{27}$

Somewhat different was the Women's Advertising Club of London (WACL). WACL provided a social space for the small numbers of senior advertising women to interact and forge business connections. Like the Thirty Club, WACL's key institution was the monthly dinner, with a high caliber of invited speakers from the arts, sciences, industry and politics. ${ }^{28}$ WACL's members worked within the constraints imposed by the gender divisions within advertising employment and adjacent sectors like magazine publishing in advancing the 
interests of senior women. This included acting as 'hostesses' at key industry events, as well as organizing philanthropic activities on behalf of the industry. These latter activities drew upon established traditions of middle class and aristocratic female volunteering and there was a meshing of WACL's membership with voluntary associations like the Women's Voluntary Service (WVS). ${ }^{29}$

WACL's members, despite the fact that they were notable joiners of industry associations and clubs like the IPA and the Publicity Club of London, remained exceptional. ${ }^{30}$ Few women were represented on the boards of agencies or acted as department heads. In this regard, forms of vertical and horizontal gender segregation in its employment structures marked the industry. This corresponded with the wider sexual divisions of labor with professional and semi-professional work at the time. In 1960, fewer than forty percent of all advertising employees were women, but the majority of these were employed in secretarial, administrative and ancillary roles. Of the minority that were employed in the core professional jobs, most worked in marketing services, including market research, the latter regarded as a female specialism. In the increasingly influential creative department, women were under-represented. Only 1 in 5 of copywriters was a woman in the late 1960s, with just over ten percent of advertising artists being women. ${ }^{31}$

If London advertising, especially at its upper echelons, represented something of a 'men's club', then the industry was also marked by its distinctive social class composition. In particular, the advertising industry was notable for the relatively high educational and social standing of its staff, with $20 \%$ of staff at the large IPA agencies coming from public school. ${ }^{32}$ This was at a time when only around $6 \%$ of the population attended public schools. ${ }^{33}$ Many of these public school recruits headed agencies. They included men like Arthur Varley, a founding partner of the top British agency CPV. For those who met him in the early 1960s, Varley appeared 'as an amiable, slightly portly good-looking old Wykehamist with a pipe and 
a tweed suit'. ${ }^{34}$ Varley's public school and Oxbridge background - he had gone to Worcester College, Oxford after leaving Winchester - was typical of agency bosses. The educational backgrounds of senior advertising managers was also broadly representative of that of top managers in the rest of British industry in this period with the concentration of graduates, including Oxbridge graduates, at the apex of advertising mirroring the educational provenance of Britain's industrial elites. ${ }^{35}$ The preference within London advertising for individuals with this kind of educational formation, alongside its pattern of gender segregation, gave notable advantages to men from privileged backgrounds. This was the case not only for those public school educated and University graduates from middling backgrounds, but also included young male aristocrats. Their presence within agencies meant that the post-war development of London advertising intersected with that of the English gentry after the war. ${ }^{36}$ Young members of the aristocracy turned to advertising and public relations out of the necessity of having to earn a living in the wake of the economic problems that faced landed estates in the years immediately after 1945. Advertising was a popular destination for both the heads and heirs of aristocratic families alongside more established occupations like the City and the new world of commercial television. ${ }^{37}$

This association between the gentry and London's large advertising agencies was signaled in a somewhat arch way in the publicity used by two prominent London agencies. Both S.H Benson and Robert Sharpe and Partners used the figure of the aristocratic 'natty gent' to personify their businesses. Robert Sharpe and Partners was headed by three old Etonians: Mark Ramage, Oliver Knox and Christopher Murray. Despite their privileged educational formation they were not members of the gentry, but drew upon the patrician image of the 'man- about- town' to sell the agency. ${ }^{38} \mathrm{~S}$. H Benson, in a series of press adverts from the mid-1950s, used a similar image to capture the ethos of the company [Figure 1]. However, the links between advertising and aristocratic culture and the wider world of social privilege 
were perhaps strongest at J. Walter Thompson’s London office. Occupying ‘impressively upholstered' office space in 40 Berkeley Square in London's Mayfair, the agency enjoyed a reputation as a 'posh agency'. ${ }^{39}$ This was evident in its informal connections with high society, as well as in the social backgrounds of its staff. Peter Ward, brother of Stephen, the chief victim of the Profumo affair, worked for the agency in the legal and personnel department and Bill Hinks, the Chairman of JWT London, had used the services of his brother, the society osteopath. ${ }^{40}$ More notable, however, was the presence in the agency's art department of Mark Birley. Birley was a well-known socialite. The son of the society portrait painter, Sir Oswald Birley, and educated at Eton he went up to University College Oxford in 1950, but never completed his studies. Instead, he joined JWT's art department. Birley enjoyed extensive connections with and inroads into aristocratic social networks. In demand as an escort for upper class young women within London society, he married Lady Annabel Vane Tempest in $1954 .^{41}$ The Marquis of Londonderry, Lady Annabel's father, was rather impressed that Birley worked in advertising, being a particular fan of the Horlicks adverts produced by the agency. ${ }^{42}$ Working for J. Walter Thompson gave Birley access to Mayfair's leisure and entertainment culture. He was a friend of John Aspinall, the owner of the Clermont Club, which had been established at 44 Berkeley Square, adjacent to J. Walter Thompson, in 1962. The club was a high class casino aimed at the well-heeled aristocracy. ${ }^{43}$ Aspinall offered Birley the basement of the Clermont to establish a new nightclub. This became Annabel's, named after Birley's wife, an up-market venue that catered for minor royals, aristocrats and celebrities. It was decorated and furnished in the 'English country house style', and mixed a traditional aristocratic ambience with up to the minute popular music. ${ }^{44}$ Annabel's was linked to the Clermont Club by a spiral staircase and there was some movement of clientele between the two clubs. One of those who moved between them was Robin Douglas Home. Home was a friend of Birley's and present at the opening of Annabel's 
in 1963, as well as playing piano at the Clermont Club in the early 1960s. He was the son of the Honourable Henry Douglas Home and the nephew of the Tory Prime minister Alec Douglas Home. Educated at Eton, he had served as an officer in the Seaforth Highlanders and was, unlike Birley, a genuine blue blood. He also worked for J. Walter Thompson as a copywriter in the late 1950s and as a consultant in the mid-1960s. Douglas Home moved within elite London circles. Described by the Daily Mirror as the 'man- about- Mayfair', he performed in the evenings as a jazz pianist, appearing at exclusive London nightclubs like the Casanova Club and the Berkeley Hotel, both in Mayfair. ${ }^{45}$ Douglas Home met Princess Margeretha of Sweden in 1958 whilst he was playing piano in one of these alluring West end settings. Their romance hit the front pages of the tabloids, catapulting the modern gentry 'man-about-town' into the mass market. From this point onwards Douglas Home featured regularly in the gossip columns, with both the Mirror and the Daily Express, papers for whom he later wrote, covering his romantic liaisons. ${ }^{46}$

Douglas Home used this sophisticated image and his connections to high society and the leisure and entertainment worlds to assist JWT. Having left the agency in the early 1960s, he was hired by JWT as a consultant in 1966. By then he was known as an accomplished photographer and journalist, as well as jazz pianist. He wrote a weekly columnist for the Daily Express, a role that included reviewing pop records for the paper. Douglas Home claimed that his position at the Express gave him access to 'general trends amongst the 'pacesetters' ${ }^{47}$ He was also a contributing editor to American Vogue and an associate editor of English Vogue. These jobs placed him at the heart of the world of fashion and close to photographers, designers and models, especially, he noted, 'the unknown, up-and comings' ${ }^{48}$ JWT London used Robin Douglas Home's connections with the worlds of fashion and entertainment for the benefit of itself and its clients. As Dermot Wilson, in charge of liaising 
between the creative department and Douglas Home, conceded in a letter to his colleagues, 'Robin has a particular gift for being 'with it' ${ }^{49}$

\section{Hubert Oughton and Ashley Havinden: Gentlemanly Professional and Man-about-}

\section{Town}

If the presence at $\mathbf{J}$. Walter Thompson of socialites like Mark Birley and aristocrats like Robin Douglas Home revealed how advertising, and adjacent media industries, intersected with elite London life, bringing urbane and patrician style of masculinity into agencies, then the identities developed by other established advertising men sheds light on the way gentlemanliness could be drawn on by men from less elevated social backgrounds. We can see this at work in the identities forged by Hubert Oughton and Ashley Havinden. Neither was a product of elite education nor was they members of the aristocracy. But they both appropriated elements of gentlemanliness in their professional and private lives.

Oughton and Havinden had joined W.S. Crawford in the 1920s. The agency was led until 1950 by its charismatic founder Sir William Crawford. It explicitly positioned itself as a 'creative' agency and built up expertise in fashion advertising for clients like Simpsons, Jaeger and Richards Shops. From the 1920s Sir William had been keen to elevate the standing of the agency by taking on and associating it with 'high class' clients. He was also influenced by developments in European design and saw these techniques as helping Crawfords to stand out from what he described as the 'semi-American amorphous mass' of his competitors. ${ }^{50}$ Distancing Crawfords' approach to advertising from 'American' techniques was, in fact, key to Sir William and he prided himself on belonging to 'the school which believes in the effectiveness of understatement'. ${ }^{51}$ As Stefan Schwarzkopf has shown, Crawfords also promoted its sophistication and modernity through its modernist office 
building at 233, High Holborn. The modernist style of the building and its furnishings was sustained through the stationary letterheads used by the agency and worked to brand Crawfords around the striking look of ' 233 '. 52

Oughton and Havinden were both close to Sir William's project for the agency and by the 1950s they had reached senior positions, with Oughton succeeding Sir William as the head of the company. Hubert Oughton was born in London in 1895, the son of a diamond mounter, and grew up in unfashionable Islington. He entered advertising in 1912 after his father had shown a selection of his talented pencil sketches to the sympathetic owner of an advertising agency. In a profile in 1960, Investors Chronicle noticed his artistic abilities and described him as 'naturally creative' and as an artist. ${ }^{53}$ They also suggested that he possessed characteristics not normally present in an artist: a 'flair for organization and unerring ability to select the pre-eminent point from masses of apparently important data' ${ }^{54}$

The organizational skills, which Investors Chronicle attributed to Oughton as an agency boss, were underscored by a strongly ambitious streak in Oughton coupled with more than a touch of the workaholic's passions. The profile noted,

'An early decision ... was to indulge in a first-class season ticket for the daily train journeys to and from Town. He reasoned that physical and mental expansiveness would prove more conducive to days of achievement and fruitful work than the cramped irritating journeys of a straphanger. That this was not a form of self-aggrandizement was shown by his continuing to work ultra-long days broken only by snatched lunches of poached eggs on toast. [..] Like most busy people, he usually finds time for the extra duties nobody else wishes to shoulder'. 55

Oughton identified with the world of business, describing himself a 'disciple of private enterprise'. This assertive identification could have a heroic dimension. In proposing a toast 
to his hosts, the Lord Mayor and the Corporation of the City of London, at an industry event, Oughton drew a parallel between the entrepreneurial spirit of advertising people and an earlier Elizabethan generation of traders and adventurers. As he suggested,

'[It is] a proud occasion for industry and the profession of British advertising to be within the famous walls of the Mansion House, the centre of a city which founded the world-wide trade of Country and Empire on what are now called 'Merchant Adventurers' in the century of the first Queen Elizabeth, and which, at the moment, now house[s] the modern equivalent of those Adventurers - the exponents of the craft of advertising, ${ }^{56}$

Oughton's desire to identify advertising with the heroic legacy of Elizabethan 'Merchant Adventurers' suggested the ambition to both capture the modernity of advertising at the cutting edge of commerce in the 'New Elizabethan Age' and also to hint at its antiquity and enduring character.

Oughton's comments on advertising were made in his role as the President of the Institute of Practitioners in Advertising. By the early 1950s he enjoyed a high profile within London advertising stemming from his involvement in many aspects of the life of the Institute and the wider industry. Between 1951 and 1954 he was President of the IPA and then an ex officio president from 1954 onwards. He was Honorary Treasurer of the Advertising Association from 1953and then its President in 1959/60. He sat on seventeen committees, including chairing the IPA's National Readership Survey Controlling Committee and was a member of the Board of Trade Advisory Committee on Commercial Information Overseas [Figure 2].

Underlying the breadth of the activities in which Oughton was involved was his strong sense of both the value of advertising and the importance of service to its corporate structures as the key vehicles for promoting the industry's interests. He was a man who was, as he once put it, proud of his calling and of the people in it [Figure 3]. ${ }^{57}$ 
Recognition from within the industry and beyond flowed from these high levels of service to the corporate institutions of advertising. In 1954, Oughton was the winner of the Advertising Association's MacKintosh Medal awarded for 'personal and public service on behalf of advertising'. A year later he won the Publicity Club of London cup for services to advertising and in 1960 he received the OBE in the New Year's Honours list. Through his service and this conspicuous success, Oughton was in many ways the quintessential committee man. On numerous occasions he took up the mantle in defence of advertising, seeking to emphasize its higher social purpose and its service to the wider community. For example, in a speech delivered to the IPA in 1951, he suggested that advertising was the 'Great Educator', raising public standards of health, hygiene and nutrition and even 'aesthetic standards of judgement'. Advertising, he contended, could play this social role because the industry was itself informed by 'high code of ethics' ${ }^{58}$ Two years later, writing in celebration of the fortieth anniversary of the trade paper Advertiser's Weekly, he again emphasized the 'social and economic services to the community' performed by advertising. These were services that could not be judged merely in terms of 'pounds, shillings and pence' and were the product, again, of the 'professional integrity and codes of service' promoted by the 'disciplined and organized body' of advertising led by the IPA. ${ }^{59}$

For Oughton part of the role of the IPA was to emphasize the importance of integrity within advertising at a time when American influences upon the industry were particularly strong and seen by some as a threat to its reputation. This was clear in debates about the introduction of commercial television in the early 1950s. Like many other members of the IPA, Oughton was hostile to the idea that US-style sponsored television might be introduced into the UK. Playing up an English pragmatism in a speech on the subject, he highlighted the need to indigenize commercial TV is it were to work in Britain. As he put it, if commercial TV came to this country 'it should not follow the US model of programme sponsorship, but be 
developed along 'common-sense British lines. ${ }^{, 60}$ This desire to distance the new commercial service form its American antecedent fitted with the approach articulated at his own agency, W.S Crawford, that British advertising should retain a healthy distance from its US counterpart.

Oughton's commitment to the IPA and the industry that it represented embodied an ideal of service that fitted the precepts of gentlemanliness. When he spoke about the importance to advertising of restraint, self-discipline and professional integrity he invoked a set of codes of behavior and comportment as much as the actual content of advertising practices. This investment of his time and energies in the corporate life of the industry and his insistence on advertising's wider service to society was confirmed by how Oughton dressed. Like other professional men and business men of the 1950s and early 1960s, Oughton was immaculate, but soberly dressed, in dark grey or black single-breasted suits. These were dress codes, as other have argued, that denoted self-control and a subsuming of the self to organizational goals. ${ }^{61}$ They also served to differentiate him from the less polished style of the commercial salesmen or the journalist hack.

Oughton participated in the exclusive, gentlemanly social networks enjoyed by senior industry figures. He was a member of the Art's Club and Thirty Club of London, being an especially active participant in its clubby culture of the latter. These advertising clubs copied the traditions of the established gentlemen's clubs and were part of the wider entertainment culture in which advertising men, like other businessmen, participated. During the 1950s and 1960s, London's night time economy explicitly targeted businessmen, including visiting foreign businessmen, in its provision of these extra-curricular pleasures. High on the list was live theatre, restaurants, bars and cinemas, but also night clubs like The Astor in Berkeley Square, Mayfair, Churchill's Club in New Bond Street, Eve Club in Regent's Street and Murray's Cabaret Club, also in W1. Whilst bodies like the Business Travel Association had 
begun promoting these venues from the late 1950s, by the late 1960 s they were trading on the image of 'Swinging London' to promote the 'cosmopolitan ease and surging vitality' of London's nightlife. $^{62}$

If advertising clubs like the Thirty Club were part of this wider field of urban sociability, they had developed distinctive rituals of their own. One of the Thirty Club's institutions was its annual pantomime. This production afforded men like Oughton the opportunity to express their theatrical inclinations. In fact, photographs showing the Thirty Club members wearing their costumes offer a glimpse of senior advertising men at play and reveal much about its strong homo-social culture [Figures 4-6]. One manifestation of this was the requirement, in the absence of women members, for the men to play female roles in its amateur dramatics. They did so with a great deal of gusto to judge from the quality of the costumes and the way they proudly posed for the camera. The established gentlemen's clubs had long sanctioned a certain amount of transgressive behavior, though generally of the more robustly heterosexual kind. As Amy Milne-Smith has shown, the clubman was allowed and expected to have a few vices, so long as they were not 'vulgar' ${ }^{63}$ Licensed cross-dressing in theatrical productions was well-established in all male societies like single sex grammar schools, public schools and the Armed Forces, but the Thirty Club pantomimes perhaps hinted at a degree of unorthodoxy amongst Oughton and his colleagues. The 'unorthodoxy' of the Thirty Club pantomimes, however, was culturally distanced from the queer underworld of 1950s London or the more eroticized consumption of the commercial sex industry that developed in the wake of the Wolfeneden Report. ${ }^{64}$

If gentlemanliness was an important facet of Hubert Oughton's occupational identity, then it also figured in Ashley Havinden's. Havinden was born in Maidstone in Kent in 1903, the son of an unsuccessful businessman. He received a scholarship to study at Christ's Hospital 
School in Horsham, West Sussex, but left school with no formal qualifications. Like Oughton, he spent almost his entire working life at the same agency, W.S Crawford. Havinden even organized Oughton's retirement dinner party from Crawfords in 1964. Whilst Oughton was employed as an account executive before entering senior management in Crawfords, Havinden was appointed as a graphic artist, poster and advertisement designer. It was a role in which he excelled. In the 1930s he received recognition from within the advertising industry for his graphic designs for the Milk Marketing Board, Eno Fruit Salts and Chrysler. In 1951 he received the OBE in the New Year's Honours list for his services to industrial design and towards the end of his career was elevated to the position of viceChairman of Crawfords, elected to the IPA council in 1961 and was made honorary member of the Advertising Creative Circle in 1966, its highest honour.

Havinden's approach to his role as an artist in advertising owed much to the influence of European modernism on both British advertising and British art more broadly in the inter-war years. In the 1920s he had been attracted to the design style of the Bauhaus School in Germany and visited their type foundries with Sir William Crawford, the principal owner of Crawfords, in 1926. Havinden was also inspired by the work of the designer Edward McKnight Kauffer who had produced innovative poster designs for the London Underground in the 1920s. Havinden later arranged for McKnight Kauffer to work freelance for Crawfords in 1929-30. Havinden shared this enthusiasm for modernism with his younger brother John, who was one of the leading commercial photographers of the 1930s and well known for his photographs of modernist architecture. ${ }^{65}$ The brothers worked together at Crawfords, with Ashley art directing and John providing the photographs for campaigns for Eno's and Osram. The influence of European modernism extended into Havinden's personal life. In the 1930s he became part of the circle of artists and designers who supported the exiled Bauhaus designers when they arrived in London after fleeing Nazi Germany. Havinden became friends 
with two of the leading Bauhaus designers, Walter Gropius and Laszlo Moholy-Nagy, often sharing meals with Moholy-Nagy and 'having long talks on aesthetics' ${ }^{66}$ Havinden also became friends with the leading exponents of modernism in British art and design, including Henry Moore, with whom he studied in 1933, Ben Nicholson, John Piper and Barbara Hepworth. Havinden's flat in Highpoint II, the modernist high rise development built in West Hampstead, was hung with works by Nicholson and Piper. Havinden himself pursued a private interest in painting and was an accomplished textile designer. ${ }^{67}$ His own work featured in the flat alongside that of his more illustrious friends. Being an artist and part of this artistic milieu was central to Havinden's self-identity and self-image. Writing to Mr. Brame, the Chairman of Simpson's department store in Piccadilly and a longtime friend, about his retirement from Crawfords in 1967, Havinden confessed,

'I feel I am basically an artist and also as I have a well-equipped studio in the country, I am leaving Crawfords earlier than I need in order to devote myself solely to graphic design and painting, ${ }^{68}$

The 'studio in the country' was an extension built by the architect Maxwell Fry in 1961 to Havinden's country house Roxford, a Victorian and Queen Anne period farmhouse in Hertfordshire that Havinden had bought in 1949. A photograph of Havinden in the studio at Roxford in the mid-1960s emphasized his identification with the modern movement in design and his own status as an artist [Figure 7]. He stands leaning against a Barbara Hepworth sculpture that he owned (and which he had bought at 'an old friend's special price'), alongside one of his own 'cubist' paintings. ${ }^{69}$ Tellingly, however, there is a reminder of his work as an advertising man in the form of one of his illustrations for the department store, Simpson's of Piccadilly, that rests at the foot of the Hepworth sculpture. The effect of the composition was meant to impress the reader, suggesting that Havinden was at ease in the 
worlds of both fine and commercial art and able to comfortably bring them together in his life [Figure 8].

This optimistic view of the role of the artist in advertising as one who could integrate both sides of the art world was also evident in Havinden's writings. In his 1955 book, Advertising and the Artist, he set out a manifesto for how modern society, including advertising, had rendered the distinctions between pure and applied art redundant. His comments on the contemporary artist in advertising can be read as disclosing much about how he saw himself:

'The top designers in advertising today ... are mature creators in their own right. Naturally, like all cultivated people, they are aware of and influenced by the form of current creative expression in literature, drama, architecture and the fine arts [but they also use their] own good taste and artistic integrity towards [their] work' ${ }^{70}$

Advertising and the Artist is also interesting for its attempts to link this vision of the artist in advertising with the wider moves to raise the standing of advertising in general. Praising the impetus within advertising towards 'self-discipline' and 'integrity', he hoped that these moves towards greater professionalism would provide an 'encouraging climate' for the artist in advertising to be given the space to thrive. Like other members of the IPA, however, Havinden suggested that artistic talent was difficult to formalize into a (professional) doctrine. As he argued, 'good taste can seldom be codified and still more rarely enforced' ${ }^{71}$ Havinden's sense of himself as a man of good taste intersected with the codes of gentlemanliness. This was evident not only in the emphasis on 'self-discipline' and 'restraint' in advertising practice, but also in how he dressed. In the 1950s and 1960s, Havinden cut a stylish figure as an immaculately attired man-about-town. Like Oughton, he participated in the gentlemanly networks of advertising clubs and was a member of the Art's Club, the Thirty Club, the Solus club and the Garrick club. ${ }^{72}$ In 1951, he featured in The Ambassador, 
the British export magazine, in an article on the style of London men. Set in the clubby atmosphere of Wheeler's Oyster Bar in Soho, Havinden was depicted wearing a tweed suit, cavalry twill waistcoat, checked shirt and tie. Whilst the turned back cuffs on his jacket hinted at a certain controlled flamboyance, his trimmed moustache and overall style confirmed the magazines' assessment of him as looking more like a 'retired military gentleman than any kind of artist' [Figure 9]. ${ }^{73}$ The Sunday Graphic, in which he appeared in an article on 'Well Dressed Men' in 1957, reaffirmed this image. It described Havinden as 'unconventional even in tweeds, but with silver-haired elegance ... the ideal English gentlemen' ${ }^{74}$ The magazine About Town also featured him in an article on 'A Man and his Clothes' in January 1961 [Figures 10-11]. Again, he looked every inch the leisured English gentleman, in a three piece tweed suit and the military moustache.

In the interview with Havinden that formed part of the About Town feature, he confessed that in his 20 s he had to wanted to be a man-about-town, but had been thwarted by his lack of money. Instead he had to make do with the off-the-peg style of Moss Bros. Career success gave him the means to pursue his youthful aspiration. He told About Town that he now had a tailor who made his suits and to which Havinden contributed design suggestions. The anecdote is important as it reveals the stylistic roots of Havinden's self-presentation in the codes of inter-war gentlemanliness that he had carried into later life. The juxtaposition of Havinden in the feature alongside other men working in the media industries underscored his generational take on stylish masculinity. He was profiled next to younger professionals, including a television producer and actor. Compared with these men, Havinden looked a little anachronistic. A function of generation and his age (he was 57), Havinden's sartorial choices contrasted with the other men who wore slimmer-fitting suits, were clean-shaven and were clearly closer to the 1960s 'revolution' in menswear than him. They looked more like the image of the new, creative professionals promoted by a magazine like London Life and 
reported on by a newspaper like the Sunday Times in the mid-late 1960 s. $^{75}$ This was a profile that was more determinedly forward-looking and which emphasized the modernity of advertising people as style-leaders within fashionable London life. It was exemplified by young ‘Turks’ like Robin Wight, Michael Beauman and Ronnie Kirkwood. Wight was interviewed in London Life when he was a 21 year-old undergraduate at St. Catherine's College, Cambridge and already forging a career in advertising through his company Precision Marketing Services. Wight was pictured wearing a flamboyant fur-coat over his suit. Beauman, an account executive at O\&M, featured in London Life's regular 'What People are Wearing' pages in a grey suit by Alexandre and a camel-coloured coat by Austin Read's 'Cue' boutique. Whilst Kirkwood, President of the Advertising Creative Circle, was shown dancing with the pop singer Millie at the Creative Circle's twenty first birthday party in a slim-line dinner jacket and waistcoat. ${ }^{76}$ Compared to this younger generation of advertising men Havinden's take of the post-war ‘man-about-town' had begun to look passé. Havinden's studio extension to 'Roxford' is also tantalizing in what it discloses about some of the tensions and contradictions within Havinden's sense of himself. As I have just noted, the decision to live in a country house fitted with Havinden's desire to live the life of an English gentleman. A period property and country life were part of this aping of patrician style. At the same time Fry's studio extension to the house, with its striking modern architecture, was absolutely consistent with Havinden's deep commitment to modernism in design and his identification with this particular vision of modernity. Yet the studio jarred badly against the original structure of the house. The relationship between these two parts of his property - the traditional Queen Anne and Victorian farmhouse and the modern 1960s studio - revealed a lack of integration of tradition and modernity, between the pull of patrician styles and the ethics of modern living, between competing parts of Havinden's sense of himself. 


\section{Conclusion}

The tension between tradition and modernity, between a forward-looking vision for advertising and modern design and the apparent antiquity of aspects of patrician style and comportment was a common element in the occupational identities forged by Havinden and Oughton. It formed a key part of how they drew upon the codes of gentlemanliness and how they combined it with other identifications, emphasizing its backward looking qualities in the process. As we have seen, their appropriation of gentlemanliness applied not only to the sartorial look of the English gentleman and his pastimes, but was also carried in the subjective comportment and ethos of gentlemanliness. We saw this in the sober, serious and understated style of Hubert Oughton. He was the consummate committee man and advocate of professional discipline and restraint in advertising. The latter were principles that he appeared to understand not just as precepts for the practice of advertising, but also as effectively masculine codes of honour. They conformed to the notion that gentlemanliness was defined by a particular personal style marked by modesty, service, understatement and the resistance to brash self-promotion.

The appropriation of codes of honour by Oughton and Havinden tells us something about the post-war currency of the gentlemanliness. Namely, that, as Andrew Miles and Mike Savage have argued, in migrating from its exclusive aristocratic anchorage, gentlemanliness could allow individuals to differentiate themselves from 'the instrumental, the vulgar, the coarse'.77 This emphasis on social differentiation helps to explain the pull of gentlemanliness to advertising people. Given the contemporary hostility to the business of selling and persuasion and some of the practices of their forebears, for some advertising men distancing themselves from the instrumental, vulgar and coarse was likely to have considerable appeal. Elevating the status of their vocation helped to move them subjectively up the cultural escalator and to raise their standing with their peers and business associates. Such a project was possible 
because of the mobile and floating character of gentlemanliness. It was an ideal, as Corfield suggests, that was rather like the Church of England: broad-based, eclectic and latitudarian. ${ }^{78}$ It was also bound up with an assertion of national difference in the face of the growing presence of American advertising in London. Asserting the values of restrained, understated English gentility was part of a reaction to the ethos and styles of US advertising, including perceptions about the brash style of the Madison Avenue 'huckster'. Whilst the recourse to gentlemanliness was only one part of their multi-facetted public identities, for men like Oughton and Havinden it was a crucial element. If they appeared as rather contradictory or divided souls, drawn towards private enterprise and the idea of the artist and designer in advertising, gentlemanliness nonetheless offered an important anchoring of their respective sense of self as leading advertising men in a time of change and growth for the London advertising industry.

\section{Notes}

${ }^{1}$ D. Sutherland Portrait of a Decade, London Life 1945-1955, London: Harrap, 1988, p125. See also the discussion of Sutherland in F. Mort Capital Affairs, The Making of the Permissive Society, London: Yale University Press, 2010, pp47-52.

${ }^{2}$ Sutherland Portrait, p225.

${ }^{3}$ C. Breward and D. Gilbert 'Anticipation of the New Urban Cultural Economy: Fashion and the Transformation of London's West End', in M. Hebler \& C. Zimmermann (eds) Creative Urban Milieus, Historical Perspectives in Culture, Economy and theCity, Frankfurt/New York: Campus Verlag, 2008, p165-6.

4 'General Advertising Service Agents, consultants, etc', in Advertiser's Annual, 1966, London, Admark Publishing.

${ }^{5}$ D. Gilbert 'The Youngest Legend in History': Cultures of Consumption and the Mythologies of Swinging London', The London Journal, Volume 31(1), 2006, pp 1-14; C. Breward, D. Gilbert, J. Lister Swinging Sixties, London: V\&A Publications, 2006; C. Breward 'Style and Subversion: post-war poses and the Neo-Edwardian Suit in mid-twentieth 
Britain', Gender \& History, Volume 14(3), 2002, pp560-82; F. Mort Capital Affairs, The Making of the Permissive Society, London: Yale University Press, 2010; J. White, London in the Twentieth Century: A City and its People (2001); D. Sutherland Portrait of a Decade: London Life 1945-55, 1988, London, Harrap; On London in the 1980s and 1990s, see F. Mort, Cultures of Consumption, Masculinities and Social Space in Late Twentieth Century Britain, 1996, London: Routledge; S. Nixon, Advertising Cultures: Gender, Commerce, Creativity, 2003, London: Sage.

${ }^{6}$ F. Mort Capital Affairs, Making of the Permissive Society, London: Yale University Press, 2010, pp 56-86.

${ }^{7}$ For a summary see S. Nixon 'Exhibiting Masculinity', in Representation, Cultural Representation and Signifying Practices, S. Hall, J. Evans, S. Nixon (eds.), London: Sage, 2013, pp294-299; and inter alia, F. Mort Cultures of Consumption, Masculinities and Social Space in Late Twentieth Century Britain, 1996, London: Routledge; M. Roper, Masculinity and the British Organisation Man, Oxford: Oxford University Press, 1994; M. Roper 'Between Manliness and Masculinity: The 'War Generation' and the Psychology of Fear in Britain, 1914-1950', in Journal of British Studies, 44(April 2005), pp343-362; G. Dawson Soldier Heroes: British Adventure, Empire and the Imagining of Masculinities, London: Routledge, 1994; J. Tosh \& M. Roper (eds.) Manful Assertions: Masculinities in Britain since 1800, London, 1991, London: Routledge; M. Francis 'A Flight from Commitment? Domesticity, Adventure and Masculine Imagery in Britain after the Second World War', in Gender \& History, Volume 19(1), April 2007, pp163-185.

${ }^{8}$ Ibid.

${ }^{9}$ N. McKendrick 'Gentleman and Players Revisited': the Gentlemanly Ideal, the Business Ideal and the Professional Ideal in English Literary Culture', in N. McKenrick \& R. B Outhwaite (eds) Business Life and Public Policy: Essays in Honour of D. C Coleman, Cambridge: Cambridge University Press, 1986, pp 98-137; W.J Reader 'At the Head of all the New Professions': the engineer in Victorian Society', in McKendrick \& Outhwaite, pp 173-184; A. Saint The Image of the Architect, New Haven \& London: Yale University Press, 1983; A.D.Pionke The Ritual Culture of Victorian Professionals, Competing for Ceremonial Status, 1838-1877, Ashgate, Farnham, 2013, pp5-8.

${ }^{10}$ P. Corfield 'The Democratic History of the English Gentleman', in History Today, 1992, 42(12), pp 40-47; M. Girouard The Return to Camelot, Chivalry and the English Gentleman, New Haven \& London: Yales, 1981; M. Collins 'The Fall of the English Gentleman: the national character in decline, c1918-1970', in Historical Research, Volume 75 (187), 2002, pp 91-111; D. Sutherland The English Gentleman, London: Seeley, 1978. 
${ }^{11}$ A. Miles \& M. Savage 'The Strange Survival of the English Gentleman, 1945-2010', in Cultural and Social History, 9(4), 2012, pp 595-612.

${ }^{12}$ McKendrick 'Gentleman and Players Revisited', p135.

${ }^{13}$ S. Schwarzkopf 'Respectable Persuaders, The Advertising Industry and British Society, 1900-1939’, unpublished PhD Thesis, Birkbeck College, University of London, 2008.

${ }^{14}$ B. Conekin, F. Mort and C. Waters 'Introduction', in Moments of Modernity, Reconstructing Britain 1945-1964, 1999, London: Rivers Oram, pp1-21.

${ }^{15}$ H. Perkin, The Rise of Professional Society, England since 1800, London, 1989, London: Routledge.

16 M. Collins 'The Fall of the English Gentleman: the national character in decline, c19181970', in Historical Research, Volume 75 (187), 2002, pp 91-111; M. Francis 'A Flight form Commitment? Domesticity, Adventure and the Masculine Imagery in Britain after the Second World War', in Gender \& History, Volume 19(1), April 2007, p170. In Martin Wiener's celebrated account, the stifling of Britain's 'industrial spirit' had come in large part from the way the sons of businessmen were 'emasculated into gentlemanliness' at public school and at elite Universities. See M. Roper Masculinity and the British Organisation Man, Oxford: Oxford University Press, 1994, pp24-5.

17 See, inter alia, S.Nixon 'Salesmen of the Will to Want: Advertising and its Critics in Britain 1951-1967', Contemporary British History Volume 24(2), 2010, pp213-235; S. Schwarzkopf 'They do it With Mirrors: Advertising and British Cold War Consumer Politics', Contemporary British History, Volume 19 (2), 2005, pp113-150.

${ }^{18}$ F. Williams The American Invasion, London: Anthony Blond, 1962; 'Those hands across the sea are getting stronger', Advertiser's Weekly, 30/1/1959, p 29; 'British Advertising is Big American Business', Advertiser's Weekly, 23/2/1962, p20; 'The Second wave', Advertiser's Weekly, 17/7/1964, p24.

${ }^{19}$ D. Higgins (ed.) The Art of Writing Advertising, Lincolnwood, Il: NTS Business Books, 1965; K. Roman The King of Madison Avenue, David Ogilvy and the Making of Modern Advertising, London: Palgrave Macmillan, 2000, p3.

${ }^{20}$ A. Sampson Anatomy of Britain, London: Hodder \& Stoughton, 1964, p627.

${ }^{21}$ S. Nixon Hard Sell: Advertising, Affluence and Trans-Atlantic Relations, circa 1951-1969, Manchester: Manchester University Press, 2013, pp 16-25. 
22 J.Tunstall, The Advertising Man in London Advertising Agencies, London: Chapman \& Hall, 1964, p 27.

${ }^{23}$ F. Mort 'The Commercial Domain: Advertising and the Cultural Management of Demand', in P. Jackson, M. Lowe, D. Miller \& F. Mort (eds.) Commercial Cultures: Economics, Practices, Cultures, Oxford: Berg, 2000; V. de Grazia Irresistable Empire: America's Advance Through Twentieth Century Europe, Harvard: Harvard University Press, 2005.

${ }^{24}$ J. O'Connor 'From Minor to Major Key', in IPA: Fifty Years of Growing Responsibility, London: IPA, 1967, p2.

${ }^{25}$ Belgrave Square was initially developed in the 1730 s and 1740s and until the 1950 s most of the houses were private residences of the aristocracy. From then on embassies and professional associations like the IPA took more of the properties. See Kelly's Directories of London; S. Bradley \& N. Pevsner, The Buildings of England, London 6: Westminster, 2003.

${ }^{26}$ M. Cudlipp The Thirty Club of London, 'Free Speech Within Four Walls'. Norwich: History of Advertising Trust \& Thirty Club of London, 1999; Thirty Club of London, List of Speakers 1962/6, TC Box 2, History of Advertising Trust (HAT).

${ }^{27}$ Sampson, Anatomy, p59.

28 'The Story of the Women's Advertising Club of London', 1965, WACL/HAT 18/4/1-2; 'WACL - Widening the Club image', WACL/HAT 2/1; AGM 14/6/1960', WACL/HAT 4/3; Executive Committee, September 1960, WACL/HAT 3/4.

${ }^{29}$ On WVS, see J. Hinton 'Voluntarism and the Welfare/Warfare State, Women's Voluntary Services in the 1940s', Twentieth Century British History, Volume 9 (2), 1998, pp 274-305.

30 'Members Activities in Advertising', June 1963, WACL/HAT 4/4

${ }^{31}$ On women in advertising, see 'Who are the Gentle Persuaders', Times, 13/4/1967, p 7 and 'The Gentle Persuaders 2', Times, 20/4/1967 p 9; J. Scanlon 'Advertising Women: The J. Walter Thompson Company Women's Editorial Department', in J. Scanlon (ed.) The Gender and Consumer Culture Reader, New York \& London: New York University Press, 2000, pp201-226.

${ }^{32}$ IPA, Agency Employment, London: IPA, 1966, p3.

${ }^{33}$ The Public Schools Commission, first report, HMSO, 1968. 
${ }^{34}$ J. Pearson \& G. Turner The Persuasion Industry, London: Eyre \& Spottiswoode, 1965, p107.

${ }^{35}$ M. Roper, Masculinity and the British Organisation Man, Oxford: Oxford University Press, 1994, p 48 \& 53.

${ }^{36}$ D. Cannadine, The Decline and Fall of the British Aristocracy, New Haven: Yale University Press, 1990, pp 637-650; R. McKibbin Classes and Cultures: England 1918-1951, Oxford: Oxford University Press, 1998, pp 42-43; P. Mandler The Rise and Fall of the Stately Home, New Haven: Yale University Press, 1997.

${ }^{37}$ D. Cannadine, The Decline and Fall of the British Aristocracy, New Haven: Yale University Press, 1990, p658.

${ }^{38}$ On Oliver Knox see Telegraph obituary 19 July 2002, p25.

${ }^{39}$ P. Yeo Reflections on an Agency, unpublished manuscript and not dated, JWT Archives, HAT Box 7-246, p6. On 40 Berkeley Square, see 'Flats and Chambers', Times, 1/4/1937, 29.

${ }^{40}$ Profile Peter ward, Round the Square, 28/11/1962, p6

${ }^{41}$ P. Yeo, Reflections on an Agency, unpublished manuscript and not dated, JWT Archives, HAT Box 7-246, p29; F. Mort, Capital Affairs, Making of the Permissive Society, London: Yale University Press, 2010, p78; 'Mark Birley, Obituary, Guardian, 29/8/2007, p23; Obituary, Daily Telegraph, 27/8/2007, p15; 'Hurley Birley', Vanity Fair, February, 2008, pp35-37.

42 A. Goldsmith, Annabel, An Unconventional Life, the Memoirs of Lady Annabel Goldsmith, London: Phoenix, 2005, p93.

${ }^{43}$ J. Pearson, The Gamblers, London: Century, 2005, p6.

${ }^{44}$ Pearson, p 160

${ }^{45}$ Daily Mirror, 16/10/1968, p3.

${ }^{46}$ See Daily Express, 7/5/1957, p5; 9/5/1957, p1; 22/2/1958, p5; 30/3/1959, p1; 14/10/1958, p9; Daily Mirror, 7/5/1957, p1; 25/9/1957, p2; 5/3/1958, p1; 11/3/1958, p1. 
47 Recorded in letter from Dermot Wilson to the Creative Department, 28 April 1964, JWT/HAT, Box 628.

48 Letter from Dermot Wilson to the Creative Department, 28 April 1964, JWT/HAT, Box 628

49 Letter from Dermot Wilson to the Creative Department, 28 April 1964, JWT/HAT, Box 628

${ }^{50}$ S. Schwarzkopf, 'Creativity, Capital and Tacit Knowledge, The Crawford Agency and British Advertising in the Inter-War Years', Journal of Cultural Economy, Volume 1(2), 2008, p186. On Crawfords see also G. H. Saxon Mills There is a Tide...The life and Work of William Crawford, K.B.E, Embodying an Historical Study of Modern British Advertising, London: Heinemann.

${ }^{51}$ S. Anthony Public Relations and the Making of Modern Britain: Manchester:MUP, 2012, p13.

${ }^{52}$ Schwarzkopf, 'Creativity, Capital and Tacit Knowledge, The Crawford Agency and British Advertising in the Inter-War Years', Journal of Cultural Economy, Volume 1(2), 2008,p191.

${ }^{53}$ Investor's Chronicle, 8/1/1960, p102.

${ }^{54}$ Investor's Chronicle, 8/1/1960, p102.

${ }^{55}$ Investors Chronicle, 8/1/1960, p102

${ }^{56}$ Institute Information, vol. 1, no. 2, 1953, p4.

${ }^{57}$ Institute Information, vol. 2, no. 1, 1955, p2.

${ }^{58}$ Advertiser's Weekly 12/7/51, p92.

${ }^{59}$ Advertiser's Weekly 16/4/53, p79.

${ }^{60}$ Institute Information, Volume 1, no 1, September 1953, p4.

${ }^{61}$ Mort, Capital Affairs, p79.

62 'Late Night London' in Business Visitor to Britain, Autum/Winter 1968, pp26-7; See also Business Visitor to Britain Autumn/Winter 1958, p13; Spring/Summer 1959, pp28-9; 
Spring/Summer 1961, pp26-7; Hotels and the Business Traveller, a Study of the use made by the business community during 1967 by British Hotel Services, Economic Development Committee for Hotels and Catering, HMSO, 1970.

${ }^{63}$ A. Milne-Smith 'Club Talk: Gossip, Masculinity and Oral Communities in Late Nineteenth Century London', in Gender \& History, Volume 21(1), April 2009, pp86-106.

${ }^{64}$ M. Houlbrook 'Soldier Heroes and Rent Boys: Homosex, Masculinities, and Britishness in the Brigade of Guards, circa 1900-1960', in Journal of British Studies, 42, July 2003, pp351388; Mort Capital Affairs, pp243-280.

${ }^{65}$ A.Simpson 'Architecture and Interiors', in Advertising and the Artist, Ashley Havinden, M. Havinden, R. Hollis, A. Simpson and A. Strang, National Galleries of Scotland, Edinburgh, 2003, p60. See John Havinden's photograph of Lubetkin's design for the Penguin Pool in London Zoo in P. Anker 'The Bauhaus of Nature', in Modernism/Modernity, Volume 12 (2), pp229-252, p237.

${ }^{66}$ Letter to Mr. Senter, 6/1/1971, GMA 39/1/093

${ }^{67}$ Havinden had a one-man exhibition of his abstract paintings at the London Gallery in 1937.

${ }^{68}$ Letter to Mr Brame, 9/3/1967, GMA 1/1/746

${ }^{69}$ Letter to Barbera Hepworth, 28/7/1964, GMA 39/1/093

${ }^{70}$ A. Havinden Advertising and the Artist, London: Studio Publishing, 1955, p15

${ }^{71}$ Havinden, p16.

${ }^{72}$ Who's Who in Advertising and Public Relations, London; New Homes press, 1963, p75.

${ }^{73}$ Sunday Graphic, 3/11/1957, p20-1

${ }^{74}$ Sunday Graphic, 3/11/1957, pp 20-1.

${ }^{75}$ See 'Who's Who', Sunday Times, 21/3/1965, pp56-57.

${ }^{76}$ London Life, 16/4/1966, p31; 2/4/1966, p26; 5/11/1966, p16. On the menswear 'revolution' of the 1960s see S. Nixon Hard Looks: Masculinities, Spectatorship and Contemporary Consumption, London: UCL Press, 1996, pp 168-177.

${ }^{77}$ A. Miles \& M. Savage 'The Strange Survival of the English Gentleman, 1945-2010', Cultural and Social History, 9(4), 2012, p603. 
${ }^{78}$ Corfield, 'Democratic History', p47. 


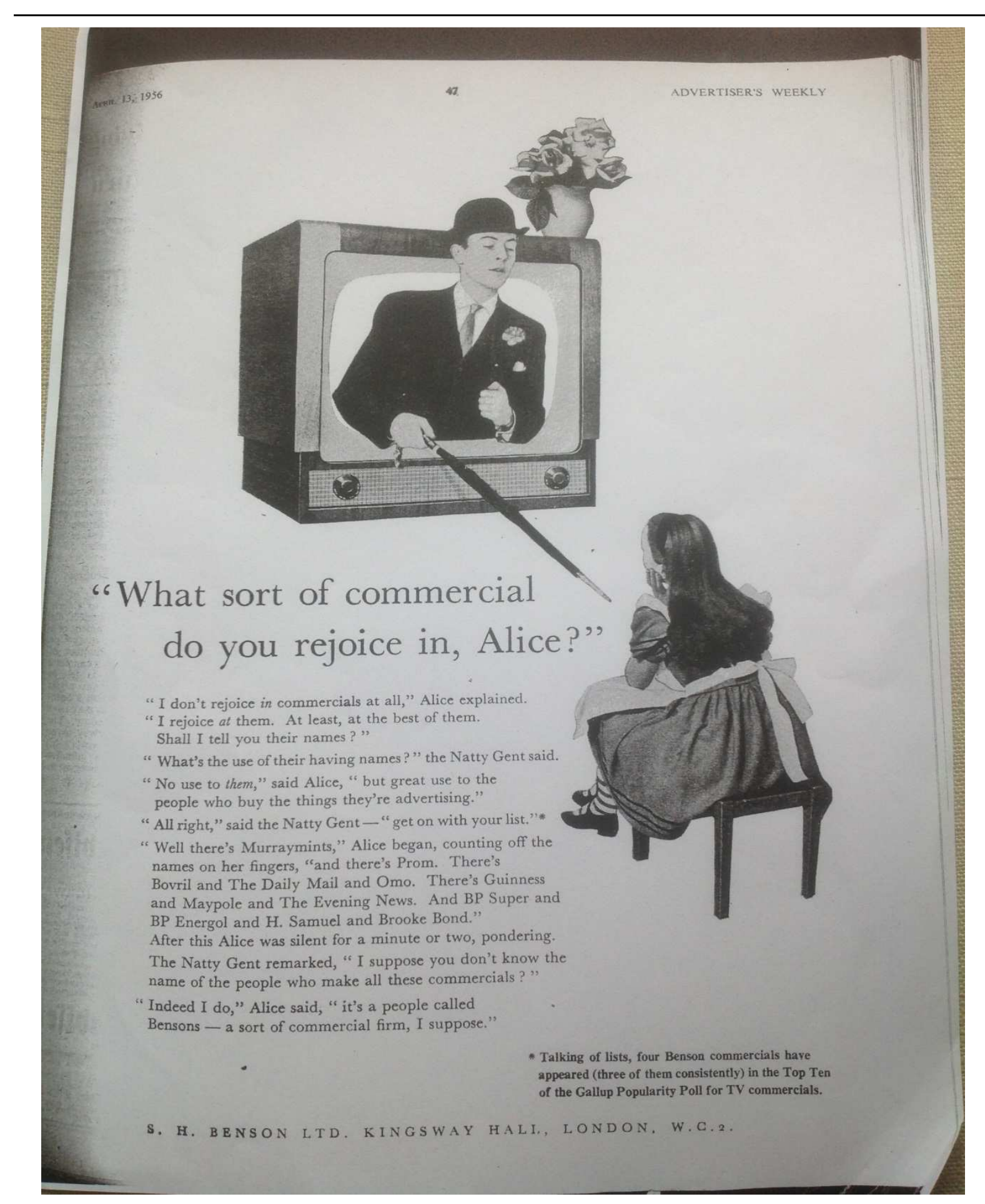

Figure 1: S.H Benson Ltd, 1956. 


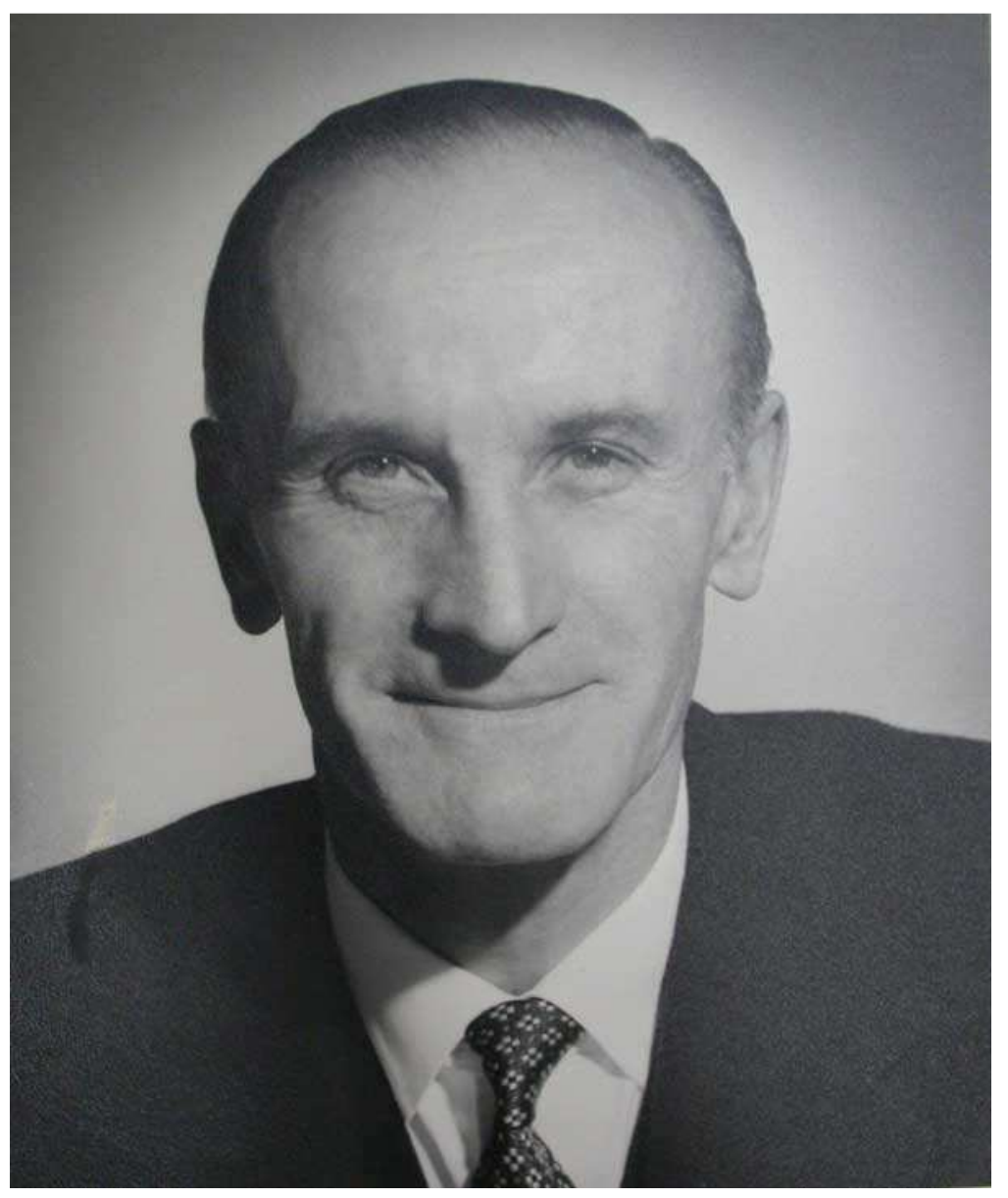

Figure 2: Hubert Oughton, IPA President, 1952. 


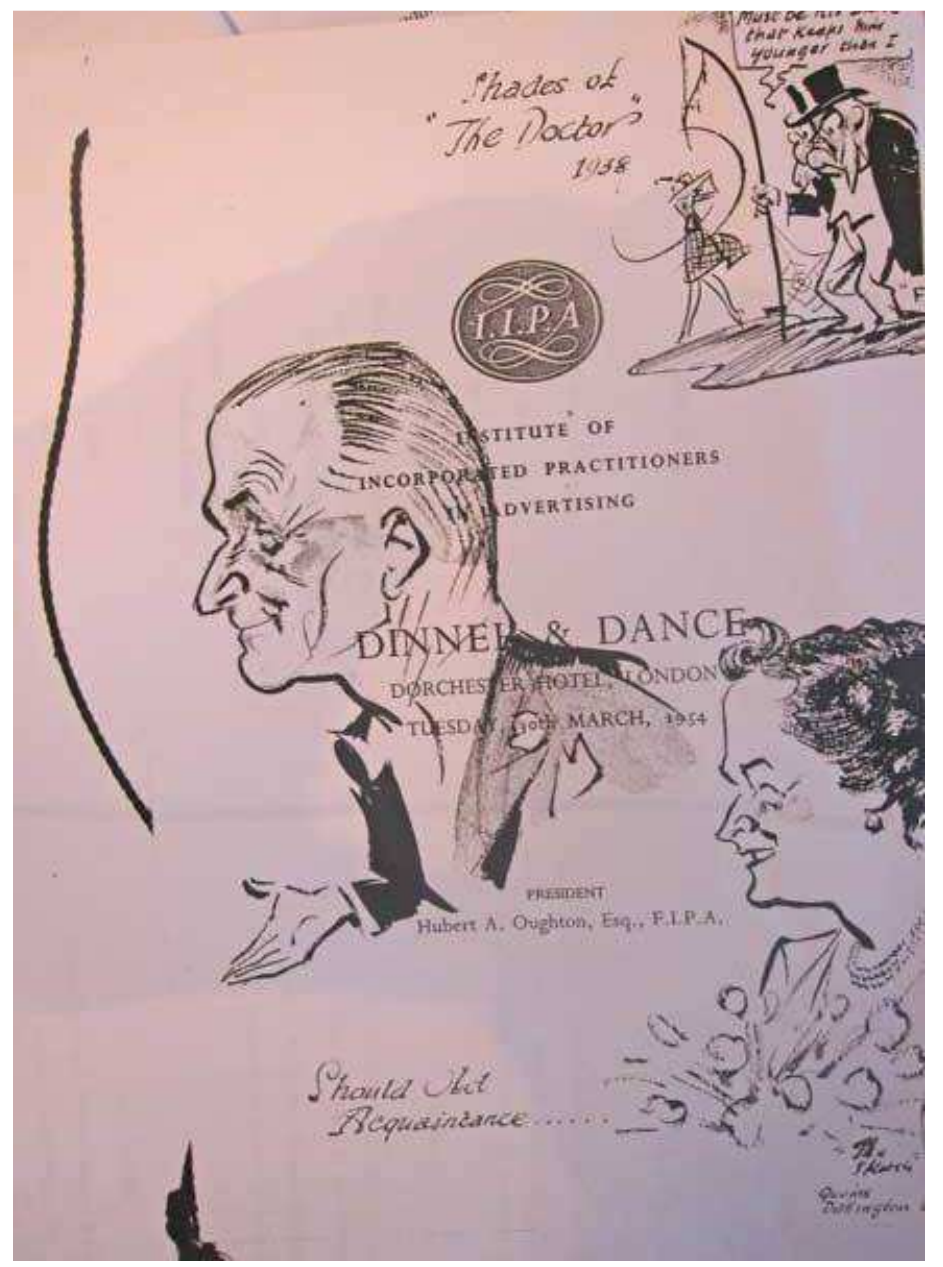

Figure 3: Hubert Oughton, caricature on IPA Annual Dinner \& Dance Menu, 1954. 


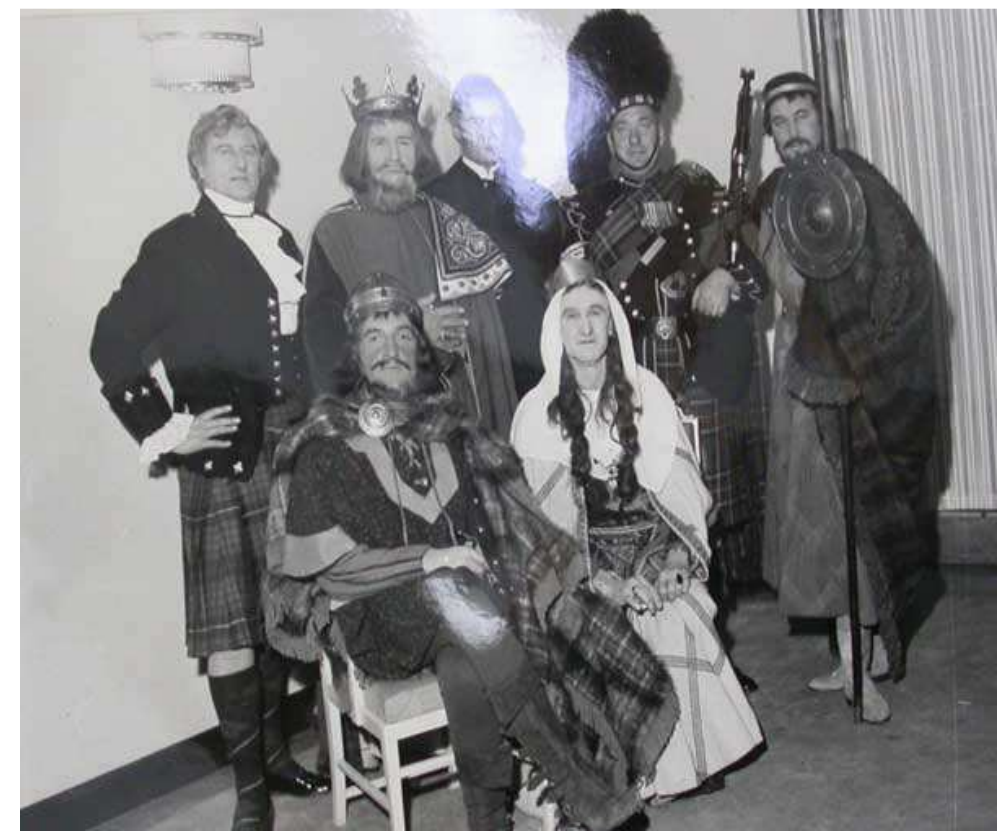

Figure 4: Thirty Club Members, Pantomime Cast, 1956. Hubert Oughton front row right seated.

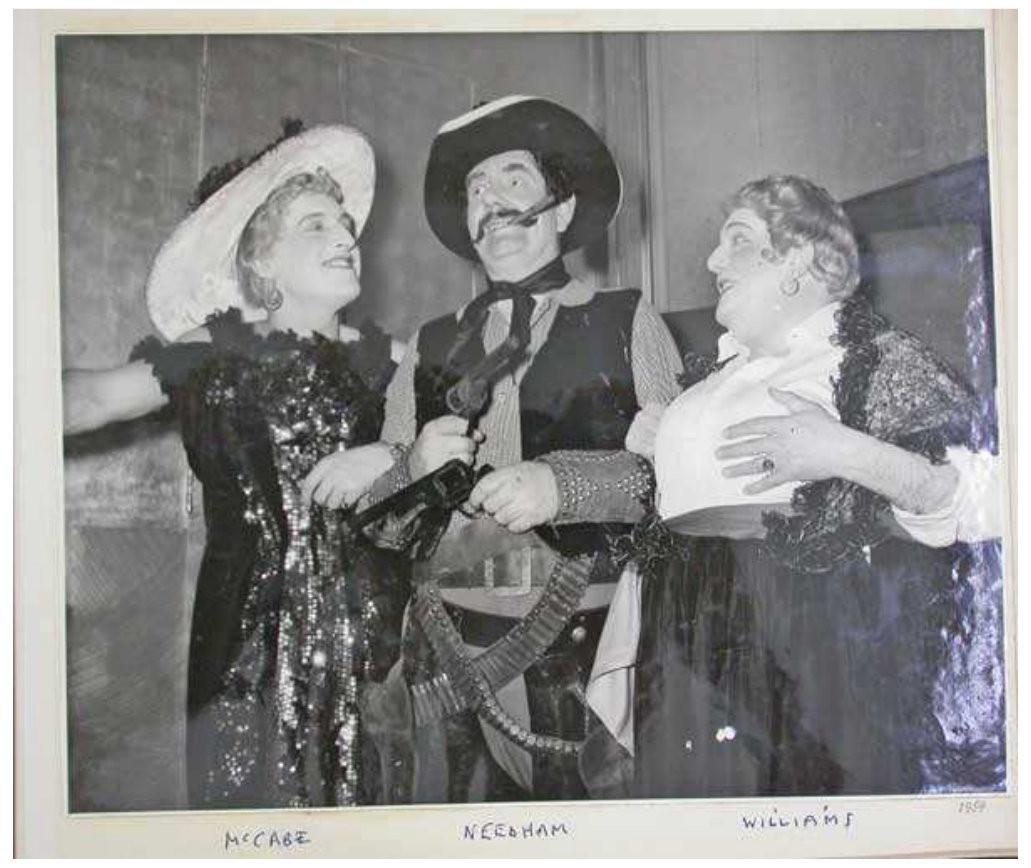

Figure 5: Thirty Club Members Pantomime, 1957. 


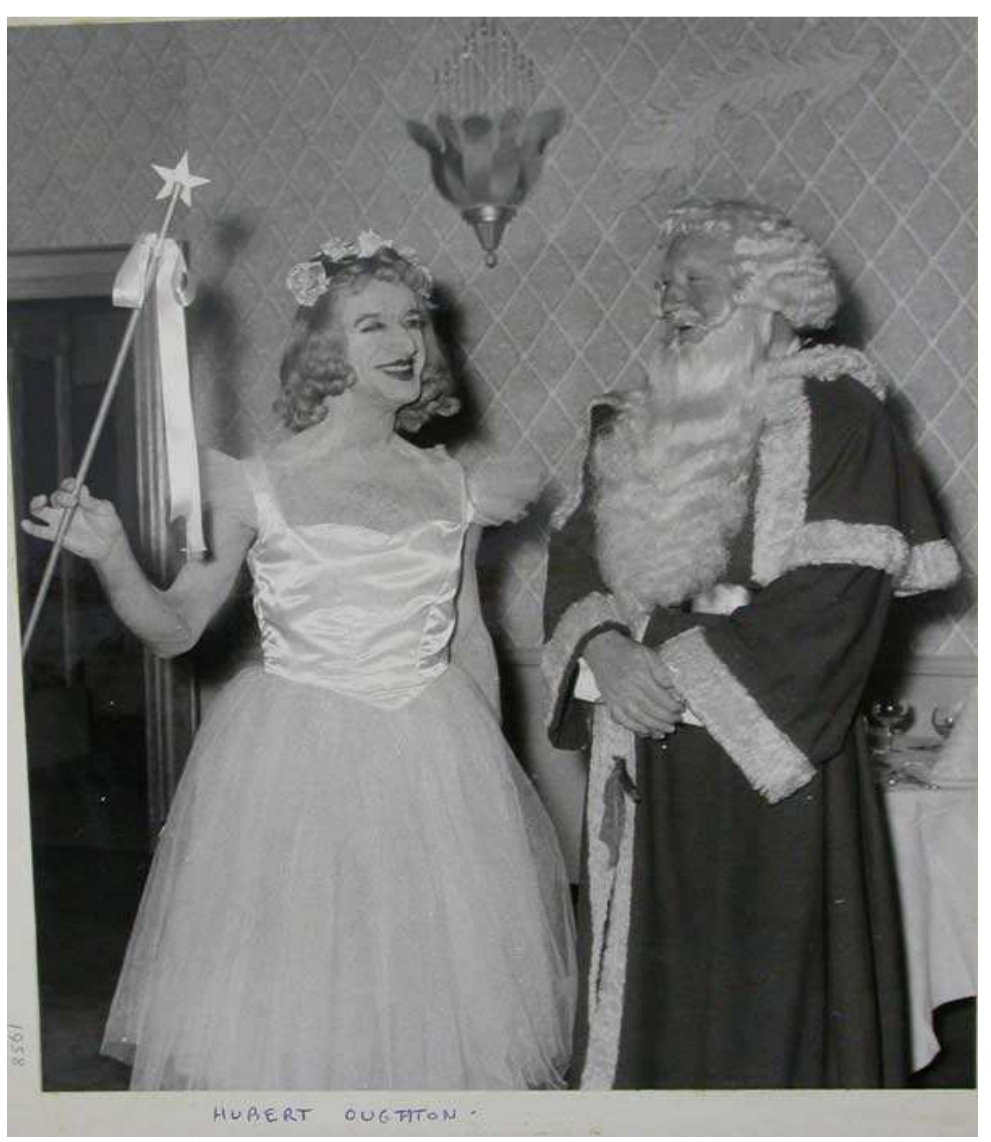

Figure 6: Hubert Oughton, left, Thirty Club Pantomime, 1958. 


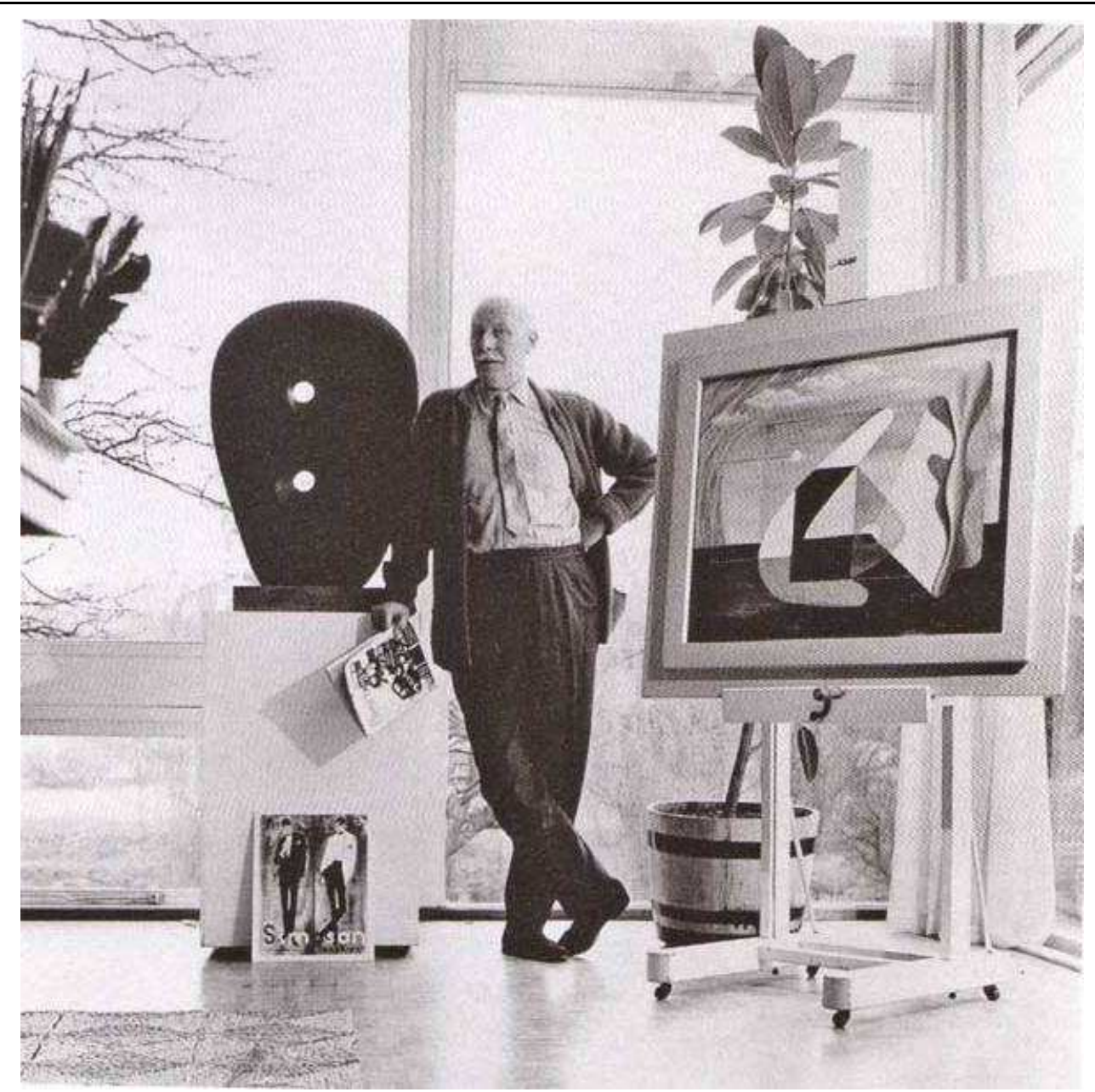

Figure 7: Ashley Havinden, 1964 

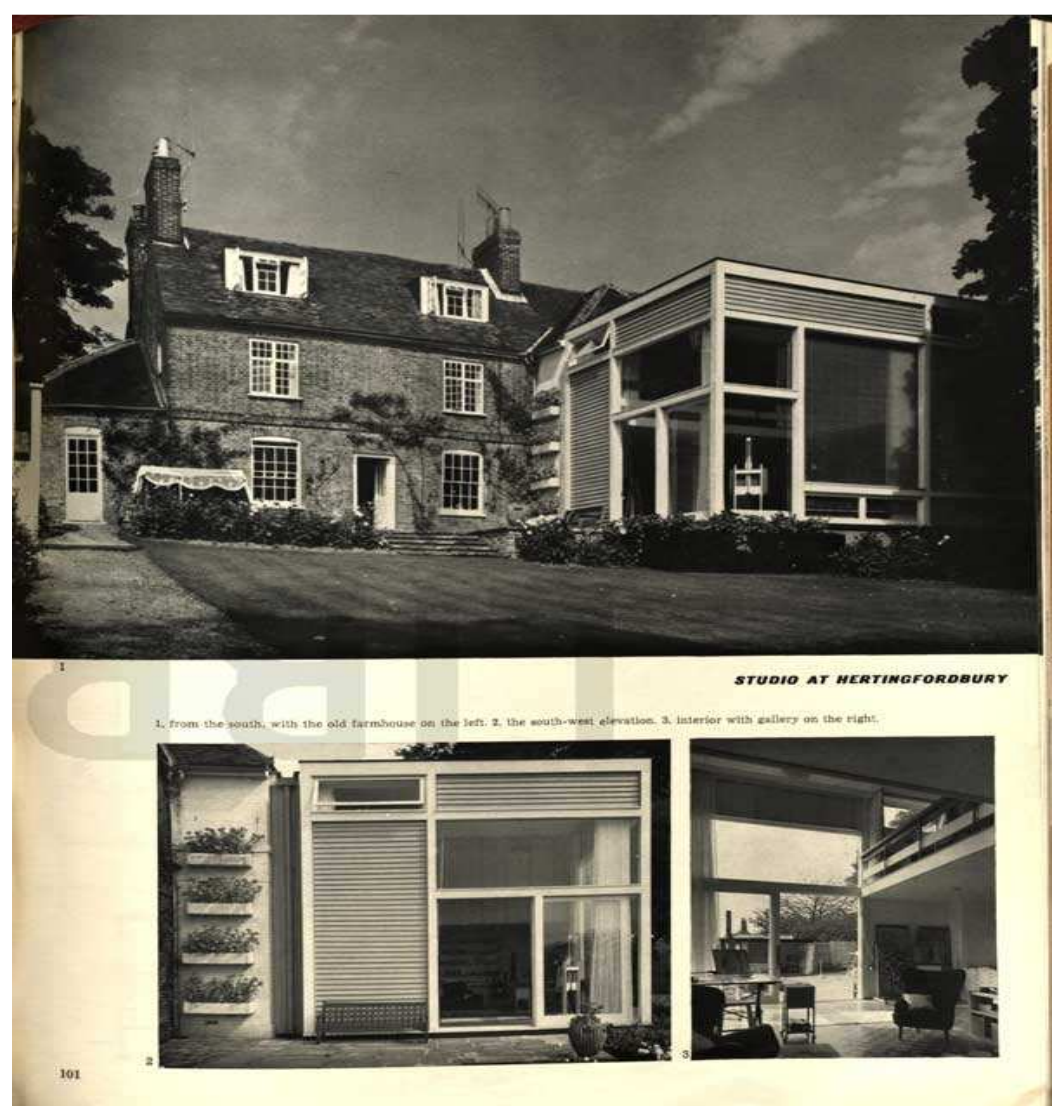

Figure 8: Roxford,

Architectural Review, January 1962 


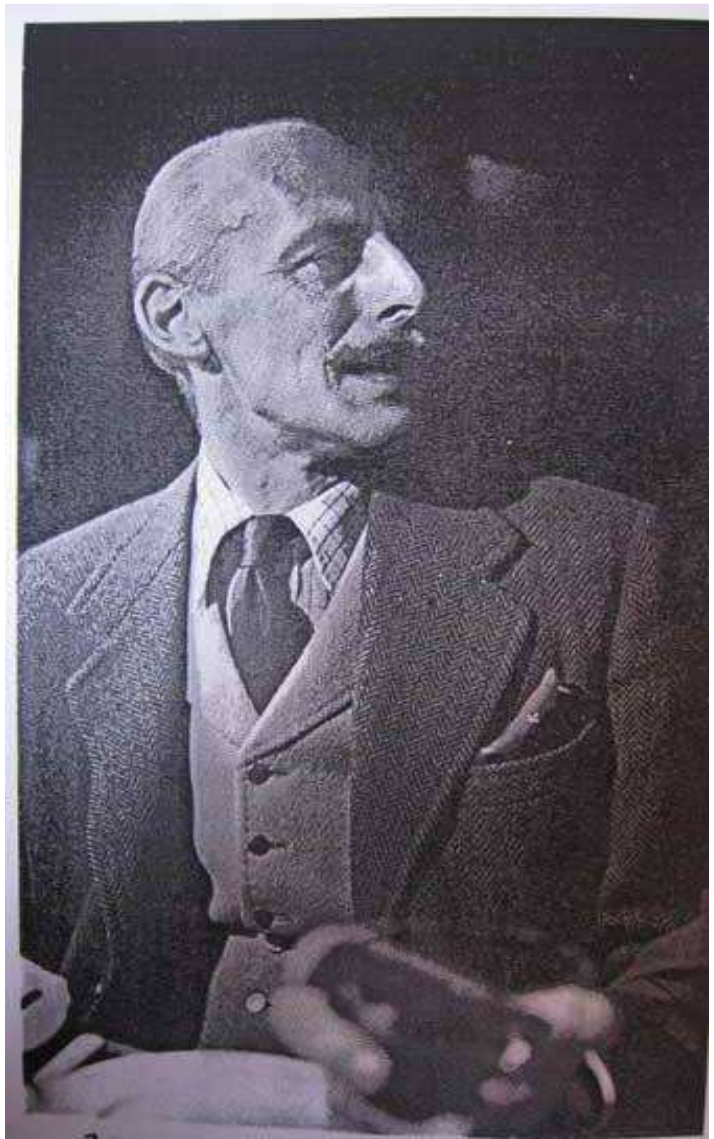

Figure 9: Ashley Haviden, 1951, The Ambassador.

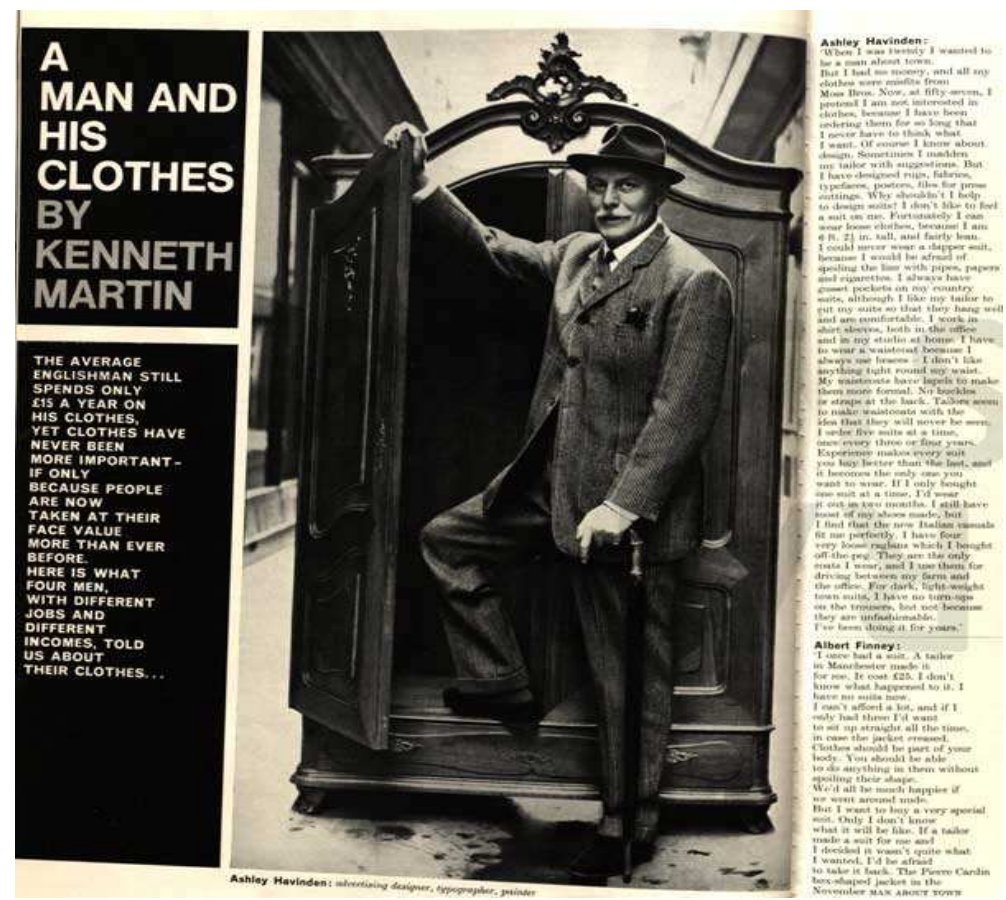

Figure 10: Ashley Havinden, 1961, About Town Magazine. 


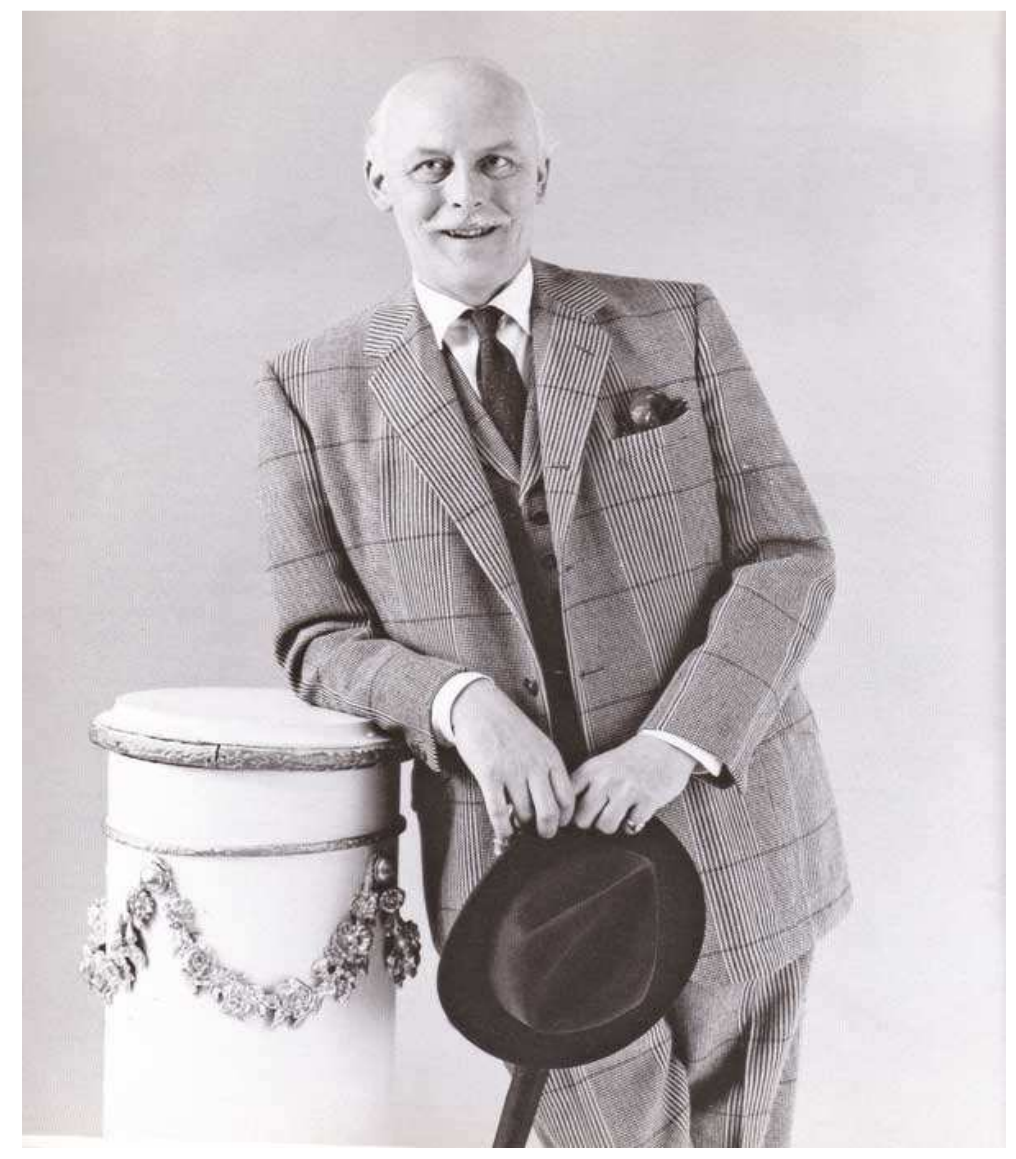

Figure 11: Ashley Havinden, 1961, About Town magazine (unpublished image). 